\title{
Antimutagenicity of Slimy Substance Separated from the Culture of Brevibacterium linens
}

\author{
Akiyoshi Hosono, Haruko Yamazaki and Hajime OTANI \\ Faculty of Agriculture, Shinshu University, \\ Minamiminowa-mura, Nagano-ken 399-45
}

(Received December 20, 1988)

\begin{abstract}
The antimutagenic effects of a slimy substance included in Brevibacterium linens on 3-amino-1, 4-dimethyl-5 H-[4, 3-b] indole (Trp-P 1), 3amino-1-methyl-5 H-pyrido [4, 3-b] indole (Trp-P 2), and heated oils (butter oil, soy bean oil and rapeseed oil) showing mutagenicty were examined in vitro using a streptomycin dependent strain, SD 510 of Salmonella typhimurium TA 98 as an indicator bacteria, and partly by high performance liquid chromatography. The slimy substance consisting of sticky materials and cells of Brev. linens exhibited remarkable antimutagenic activity towards Trp-P 1, Trp-P 2 and the mutagenic oils, when the slimy substance was incubated with either of these mutagens at $37^{\circ} \mathrm{C}$ for $15 \mathrm{~min}$. The remarkable antimutagenic activity observed was due to strong binding activity of the slimy substance to the mutagens tested.

Jpn. J. Zootech. Sci., 60 (7) : 679-685, 1989

Key words: antimutagenicity, Brevibacterium linens, slime, amino acid pyrolyzate, oil
\end{abstract}

Brevibacterium linens is a gram-positive, non-motile, asporogenous, rod-shaped organism, and it plays an important role in the manufacture of surface ripened cheeses like Limburger, Olomouc and Brick. During the ripening process of such cheeses Breu. linens produces its characteristic flavour and sticky slime ${ }^{1)}$.

In our previous paper ${ }^{2)}$, we reported that the cell wall preparation of Streptococcus faecalis was effective for suppression of the induction of mutagenesis in Escherichia coli $\mathrm{B} / \mathrm{r}$ WP $2 \mathrm{trp}^{-} \mathrm{hcr}^{-}$by standard mutagens such as 2-(2-furyl)-3-(5-nitro-2-furyl) acrylamide (AF 2) and 4-nitro-quinoline-1-oxide (4 NQO). In addition, the cell wall preparation exhibited apparent antimutagenic activity against the mutagenic fecal extracts of dogs and cats. Morotomi and MutaI also have recently reported that Trp-P 1 (3-amino-1, 4-dimethyl-5 H-pyrido [4,3-b] indole) and Trp-P 2 (3-amino-1methyl-5 H-pyrido [4,3-b] indole) were effectively bound to all gram-positive and some gram-negative bacterial cells isolated from human feces ${ }^{3)}$. The antimutagenic activity of the cell wall fraction was supposedly due to the binding of mutagens to the carbohydrate moieties.

Given these facts, the present study was undertaken, in order to investigate the antimutagenic activity of the slimy substance separated from the culture of Breu. linens on mutagenicity induced by amino acid pyrolyzates and heated oils having 
mutagenicities to a streptomycin dependent strain of Salmonella typhimurium TA 98.

\section{Materials and Methods}

\section{Strain used}

Brev. linens, which was kindly supplied from der Milchwirtschafliches Institute der Technischen Hochschule München, was used in this work. The strain was incubated at $21^{\circ} \mathrm{C}$ and transferred every three days in a PGM-medium ( $\left.\mathrm{pH} 7.0\right)$ containing peptone $1 \%$, glucose $1 \%$, meat extract $1 \%$ and sodium chloride $0.5 \%$.

The streptomycin dependent strain, SD 510 of $S$. typhimurium TA 98, used throughout this work for testing antimutagenic activity, was cultured and maintained in SM 20 agar, as reported previously ${ }^{4)}$.

2. Preparation of slime produced by Breu. linens

One liter of PGM-medium described above was dispensed in $250 \mathrm{ml}$ quantities in $500 \mathrm{ml}$ shaking flasks, and inoculated with $20 \mathrm{ml}$ of $48 \mathrm{hrs}$ ' culture of Brev. linens. They were incubated on a reciprocal shaker (140 reciprocations per minute) at $21^{\circ} \mathrm{C}$. After five days' incubation, the slime was harvested by centrifugation at 5,000 r.p.m for $30 \mathrm{~min}$ and washed twice with $50 \mathrm{~m} l$ of sterile distilled water. The slime washed was lyophilized and kept in a refrigerator until further use.

3. Assay for antimutagenicity

Tester strain, SD 510 grown in SM 20 broth overnight to an optical density of 1.3 at $660 \mathrm{~nm}\left(5.0 \times 10^{8}\right.$ viable cells $\left./ \mathrm{m} l\right)$ was suitably diluted in $0.05 \mathrm{M}$ phosphate buffer, pH 6.8, and a portion of $0.1 \mathrm{~m} l$ culture $\left(5.0 \times 10^{5} / \mathrm{ml}\right)$ was tested. With disc assay $190 \mu \mathrm{l}$ of the slime suspension (5 mg of the lypophilized slime/950 $\mu l$ of distilled water) and $50 \mu l$ of a concentration range of a mutagenic sample were mixed, incubated at $37^{\circ} \mathrm{C}$ for $15 \mathrm{~min}$, and $40 \mu \mathrm{l}$ discharged on a sterile $8 \mathrm{~mm}$ paper disc placed on a Nutrient Broth, No. 2 (Oxoid)-agar plate previously lawned with $100 \mu l$ tester strain. As a control, $190 \mu l$ of distilled water was used instead of $190 \mu l$ of the slime preparation. Plates were incubated at $37^{\circ} \mathrm{C}$ for $48 \mathrm{~h}$ and colonies counted. Results were exposed as revertants/plate after substracting the spontaneous revertants on their respective control plates. All the experiments were repeated at least twice with triplicates each time. The mean of two experiments is presented here.

4. Preparation of mutagens

Amino acid pyrolyzates (Trp-P 1 and Trp-P 2), and heated edible oils (butter, soy bean and rapeseed oils) were used as mutagens. One milligram of Trp-P 1 or Trp-P 2, which was purchased from Wako Pure Chemical Industry, Tokyo was dissolved in $1 \mathrm{~m} l$ of methanolic solution and used for the experiment. The oils were kindly supplied by Nippon Oil \& Fats Co., Ltd, Tokyo. Ten milliliters of each oil sample were heated at $160^{\circ} \mathrm{C}$ for $1 \mathrm{~h}$ in a dish $(\phi 90 \mathrm{~mm})$. An aliquot of the oil heated was added to the same volume of dimethyl sulfoxide (DMSO). From the assay conducted with the SD 510 strain, all the oil samples heated were found to be mutagenic.

5. In vitro binding assay by HPLC

Five milligrams of the freeze dried slimy material prepared from the culture of 
Brev. linens were suspended in $950 \mu l$ of distilled water. To this suspension, $100 \mu l$ of methanolic solution of Trp-P $1(200 \mu \mathrm{g} / 100 \mu l)$ or Trp-P $2(200 \mu \mathrm{g} / 100 \mu l)$ were added, and the mixture was incubated at $37^{\circ} \mathrm{C}$ for $15 \mathrm{~min}$. After incubation, the mixture was filtered with a milipore filter (poresize ; $0.4 \mu \mathrm{m}$, Fuji Film Micro Filter, Tokyo). The filtrate obtained was mixed with an equal volume of acetonitrile. Amino acid pyrolyzate, if present in the filtrate, was identified by high-performance liquid chromatography (HPLC, Shimadzu LC-6 A liquid chromatograph). The conditions for HPLC were as follows: The column for HPLC was Shim-Pack CLC-ODS, $(6 \mathrm{~mm} \times 15$ $\mathrm{cm})$; the eluting solvent was acetonitrile- $\mathrm{H}_{2} \mathrm{O}$-triethyl-amine $(50: 50: 0.5 \mathrm{v} / \mathrm{v})$; the flow rate was $1.0 \mathrm{ml}$ per min ; a UV detector was used at $280 \mathrm{~nm}$.

For control experiments, $950 \mu l$ of distilled water were used instead of $950 \mu l$ of distilled water suspending $5 \mathrm{mg}$ of the freeze dried slime. The experiments were repeated twice.

6. Estimation of peroxide of fat sample

The peroxide values of the oil samples heated at $160^{\circ} \mathrm{C}$ for $1 \mathrm{~h}$ were estimated according to a general method $^{5 \text {. }}$.

7. Electron microscopy

The slimy substance was shadowed with gold vapor and viewed with a JSM-35 electron microscope at $25 \mathrm{kV}$.

\section{Results}

Fig. 1 shows a scanning electron microscopic view of the slimy substance separated from 48 hrs' culture of Brev. linens. As observed, the slimy substance contains a large number of Brev. linens cell, with sticky materials attached to the cells. Table 1 shows antimutagenic activity of the slimy substance on the amino acid pyrolyzate-induced mutagenicity with regard to the SD 510 strain of S. typhimurium TA 98 . The control sample $\left(\mathrm{H}_{2} \mathrm{O}+\operatorname{Trp}-\mathrm{P} 1\right.$ or $\mathrm{H}_{2} \mathrm{O}+$ Trp-P 2) contained 304 or 495 revertants/plate,

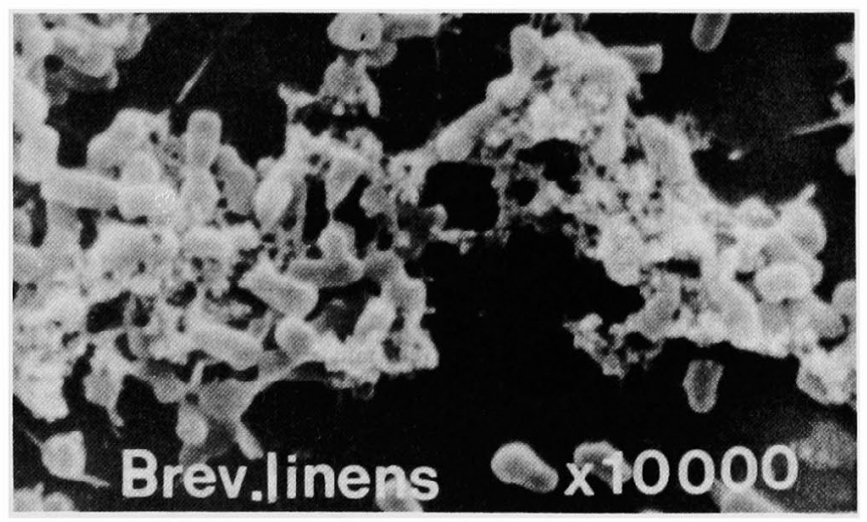

Fig. 1. Electron micrograph of the sticky slime separated from the culture of Brevibacterium linens. 
respectively. However, apparent antimutagenicity was observed via incubation with the slimy substance. With Trp-P 1 the number of induced revertants were 36 revertants/plate, but with Trp-P 2 there were none.

High-performance liquid chromatograms of Trp-P 1 and Trp-P 2 solutions, and of the filtrates obtained after the treatment of respective mutagens with the slimy substance, are shown in Fig. 2. From these chromatograms; it can be noted that

Table 1. Antimutagenicity of the slimy substance against Trp-P1 and Trp-P2

\begin{tabular}{lcc}
\hline \hline Mutagen & Control & $\begin{array}{l}\text { Treatment with the } \\
\text { slimy substance }\end{array}$ \\
\hline \multicolumn{3}{c}{ Revertants/plate } \\
Trp-P1 & 304 & 36 \\
Trp-P2 & 495 & Nil \\
\hline
\end{tabular}

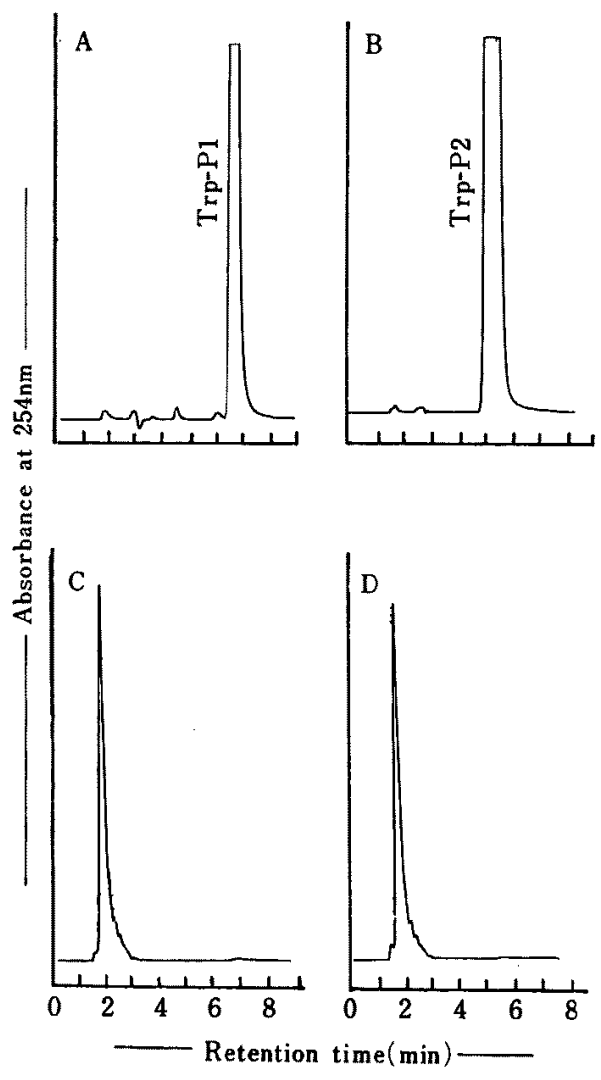

Fig. 2. Binding of Trp-P 1 and Trp-P 2 to the slimy substance prepared from the culture of Brevibacterium linens.

High-Performance Liquid Chromatogram of Trp-P 1 (A) or TrpP 2 (B) was compared with that of the filtrate obtained after the treatment of Trp-P 1 (C) or Trp-P 2 (D) with the slimy substance, respectively. 
Antimutagenic Activity of Brevibacterium linens

Table 2. P.O.V. and mutagenicities of oil samples used

\begin{tabular}{lcc}
\hline \hline Oil sample & P.O.V. & $\begin{array}{c}\text { Mutagenicity } \\
\text { (Revertants/plate) }\end{array}$ \\
\hline Butter oil & 1.5 & $\mathrm{Nil}$ \\
Heated butter oil & 42.5 & 721 \\
Soy bean oil & 0.8 & $\mathrm{Nil}$ \\
Heated soy bean oil & 17.0 & 1125 \\
Rapeseed oil & 1.0 & $\mathrm{Nil}$ \\
Heated rapeseed oil & 24.5 & 1010 \\
\hline
\end{tabular}

Table 3. Antimutagenicity of the slimy substance against heated oil samples

\begin{tabular}{lcc}
\hline \hline Mutagen & Control & $\begin{array}{c}\text { Treatment with the } \\
\text { slimy substance }\end{array}$ \\
\hline $\begin{array}{l}\text { Heated } \\
\text { butter oil }\end{array}$ & 707 & Revertants/plate \\
$\begin{array}{l}\text { Heated } \\
\text { soy bean oil }\end{array}$ & 1075 & 76 \\
$\begin{array}{l}\text { Heated } \\
\text { rapeseed oil }\end{array}$ & 967 & Nil \\
\hline
\end{tabular}

Trp-P 1 and Trp-P 2 were effectively bound to the slimy substance. Percentages of bound amino acid pyrolyzates to the slimy substance were roughly estimated to be 99.8 $\%$ for Trp-P 1 and $99.9 \%$ for Trp-P 2, respectively.

The above study led to a further investigation by use of the oils showing mutagenicity. As shown in Table 2 peroxide values of butter, soy bean and rapeseed oils increased sharply after heating at $160^{\circ} \mathrm{C}$ for $1 \mathrm{~h}$, and SD 510 strain exhibited a sharp response after all the heated oils showed complete toxicity. Table 3 shows the antimutagenicity of the slimy substance by incubation with these oil samples. While DMSO control (DMSO + heated butter oil, DMSO + heated soy bean oil or DMSO + rapeseed oil) showed maximum mutagenicity, which was 707 revertants/plate for heated butter oil, 1075 revertants/plate for heated soy bean oil and 967 revertants/ plate for heated rapeseed oil, respectively, the slimy substance separated from the culture of Brev. linens showed a significant decrease by about $89.3 \%$ in case of the heated soy bean and rapeseed oils.

\section{Discussion}

In the present study, direct evidence for antimutagenicity of the slimy substance separated from the culture of Brev. linens against amino acid pyrolyzates and heated oils showing mutagenicity was clearly demonstrated as measured by the induced mutation of SD 510 strain of S. typhimurium TA 98 . The degree of binding abilities of the slimy substance to all mutagens examined in this experiment was similar to the results obtained in our previous work ${ }^{27}$, in which the cell wall preparation of $S$. faecalis 
was especially effective for suppression of the induction of mutagenesis in Escherichia coli B/r WP $2 \mathrm{trp}^{-} \mathrm{hcr}^{-}$strain by AF 2 and 4 NQO. In general, cell walls of microorganisms are widely known to have antitumor and antimutagenic activities. Polysaccharide complex prepared from bacteria such as Corynebacterium parvum $^{6}$, Rhodococcus lentifragments ${ }^{7)}$, BCG organisms ${ }^{8,99}$, Lactobacillus casei ${ }^{10)}$, L. bulgaricus ${ }^{11)}$ and others were reported to be active against solid tumors.

A relevant question concerns the mechanisms of antimutagenic action of the slimy substance separated from the culture of Brev. linens. As observed in Fig. 2, it is clear that Trp-P 1 and Trp-P 2 were very effectively bound to the slimy substance, and antimutagenic activity of the slimy substance could possibly be due to binding of each mutagen to the carbohydrate moieties present in both the sticky materials and cell walls of Brev. linens, although no evidence has currently been obtained to support this hypothesis. In this context other interesting observations have been reported. Our previous report described the antimutagenic activity of crude walls and trypsin-treated cell walls of S. faecalis IFO 12965 on amino acid pyrolyzate-induced mutagenicity to the SD 510 strain, and showed that the increasing concentration of a salt like $\mathrm{MgCl}_{2}$ had little effect on the antimutagenicity of the cell walls of S. faecalis ${ }^{12)}$. Recently, Morotom and MUTAI have also reported on the ability of 22 strains of intestinal bacteria to bind the mutagenic pyrolyzates such as Trp-P 1, Trp-P 2 and Glu-P 1, and reported that the binding was mostly due to an ionexchange mechanism ${ }^{3)}$. KAWAKISHI et al. studied mutagen-binding properties of defatted copra meal and its derived products, and reported that carbohydrate moieties present in the meal effectively bound Trp-P 1 and AF $2^{13)}$.

Among many types of mutagens which are now being found in our daily foods, amino acid pyrolyzates like Trp--P 1 and Trp-P 2, and oils having higher P.O.V. are most common. From the viewpoint of cancer prevention, substances having antimutagenic activity and/or which suppress various steps of the cancer process, have been studied by many workers. In this respect, milk, cultured milk and other products have become of major interest lately, because of their high antimutagenic and antitumor properties ${ }^{14-17)}$. In this regard, the present findings that the slimy substance consisting of sticky materials and cells of Brev. linens exhibited remarkable antimutagenic activity towards Trp-P1, Trp-P 2 and the mutagenic oils have an important bearing in evaluating the nutritional and therapeutic values of milk products, because Brev. linens is usually used as a starter bacteria for the manufacture of soft ripened cheeses like Limburger, Brick and Olomouc.

\section{Acknowledgement}

The authors thank Ir. R. WARDOJo, a Monbusho Scholarship student from Indonesia for his help in HPLC analysis. This work was supported in part by Nippon Oil \& Fats Co., Ltd. 


\title{
References
}

1) KaLAB, M. and V. PaLo, Milchwiss., 42 : 207-211. 1987.

2) Hosono, A., A. Yoshimura and H. Otani, Neth. Milk and Dairy J., 41: 239-245. 1988.

3) Morotomi, M. and M. Mutai, N. Natl. Cancer Inst., 77 : 195-201. 1986.

4) Hosono, A., E. OMote, Y. Izawa and F. Tokita, Lebensmitt.-Wiss. u-Tech., 19 : 161163. 1986.

5) Dep. Agric. Chem., Fac. Agric,, Univ. Tokyo, Jikken Nogei Kagaku (Vol. 2). 143-144. Asakura Shoten. Tokyo. 1978.

6) Cantrell, J.L. and R.W. Weat, Cancer Res., $79: 3554-3563.1979$.

7) Hirai, O., T. Fujitsu, J. Mori, H. Kikuchi, T. Kada, M. Fujioka and Y. MoRIмото, J. Gen. Microbiol, 133 : 369-373. 1987.

8) Klein, E., Natl. Cancer Inst. Monog., 39: 139-163. 1973.

9) Kato, I., S. Kobayashi, T. Yokokura and M. MutaI, Gann, 72 : 517-523. 1981.

10) Mashiba, H., M. Gojobari and K. Matsunaga, Gann, 68: 703-708. 1977.

11) Rerspm, J.W., S.D. Chaparas and M.A. Chirigos, Cancer Res., 33 : 1845-1848. 1973.

12) Hosono, A., A. Yoshimura and H. Otani, Milchwiss., $43: 168-170.1988$.

13) Kawakishi, S., Saittagaroon and M. Namiki, Lebensmitt. -Wiss. u-Tech., $20: 83-85$. 1987.

14) Hosono, A., T. Kashina and T. KadA, J. Dairy Sci., 69: 2237-2242. 1986.

15) Hosono, A., K.N. Shashikanth and H. Otan, J. Dairy Res., 55 : 435-442. 1988.

16) Kitazawa, H., T. Toba, T. Iтoh, S. Adachi and N. Kumano, Milchwiss., 42 : 578-579. 1987.

17) Kitazawa, H., T. Toba, T. Itoh, S. Adachi and N. Kumano, Agric. Biol. Chem., 52 : 2331-2332. 1988.

\section{Brevibacterium linens の培養液から調製した 高粘質性物質の抗变異原性}

\author{
細野明義・山崎治子・大谷 元
}

信州大学農学部, 長野県南箕輪村 399-45

Brevibacterium linens の培養液より調製した高粘 質性物質 (Brev. linens の菌体之粘着性物質の混合物) を試料とし，この物質の Trp-P 1，Trp-P 2 および 160 ${ }^{\circ} \mathrm{C} ， 1$ 時間の加熱によって変異原性が認められたバター 油，大豆油，アブラナ油に対する抗変異原性について検 討した，それぞれの変異原物質に上記の高粘性物質を加 え， $37^{\circ} \mathrm{C}$ で 1 時間保温した後，上澄液を得た。この上 澄中の変異原性の有無を Salmonella typhimurium TA 98 より造成したストレフトマイシン依存性株（SD
510 株）を指標菌に用いて調べた。 また，Trp-P 1 お よび Trp-P 2 に対する抗変異原性の検討については高 速液体クロマトグラフィーを併用して調べた，その結果， いずれの場合とも上澄液中には变異原性がほとんど，ま たは全く認められず，Brev. linens の培養液から調製 した高粘質性物質には供試の変異原物質を強く吸着する 性質のあることが認められた.

日畜会報，60(7)：679-685, 1989 